\title{
Time Horizon, Costs of Equity Capital, and Generic Investment Strategies of Firms
}

Thomas Zellweger

\begin{abstract}
Recent literature (McNulty, Yeh, Schulze, \& Lubatkin, 2002) states that the assumptions behind the capital asset pricing model, in particular the irrelevance of time horizon, do not correspond to the characteristics of firms that prefer long-term investment horizons. I show that family firms display a longer time horizon than most of their nonfamily counterparts, since (1) family firms display a longer CEO tenure, (2) this type of firm strives for long-term independence and succession within the family, and (3) due to the fact that family firms are overrepresented on western European stock markets in cyclical industries in which business cycles inhibit short-term success. As the annual default risk of an investment diminishes with increasing holding period (Hull, 2003), the risk-equivalent cost of equity capital of firms with longer planning horizons (e.g., family firms) can be lower as well. Based on the assumption that economic value to shareholders is created when firms invest in projects with returns above the associated cost of capital (Copeland, Koller, \& Murrin, 2000), I argue that long-term-oriented firms can tackle unique investment projects represented by two generic investment strategies - the perseverance and the outpacing strategy. The first one, the perseverance strategy, represents investment strategies in which long-term-oriented firms invest in lower return but equal risk projects than their more short-term-oriented counterparts. The second one, the outpacing strategy, comprises investment projects with higher risk and equal return than the short-term competitors.
\end{abstract}

\section{Introduction}

Although the capital asset pricing model (CAPM) (Black, 1972; Lintner, 1965; March \& Shapira, 1987; Mossin, 1966; Ross, 1976; Sharpe, 1964) is still considered as the standard formula for estimating the cost of equity capital of a project, it displays some important shortcomings. McNulty et al. (2002) find three central shortcomings of CAPM, namely, the validity of beta, the reliance on historical data, and the indifference of the holding period.

The first two deficiencies have been widely discussed in the literature (validity of beta: e.g.,
Cannella \& Lubatkin, 1993; Chatterjee, Lubatkin, \& Schulze, 1999; Lubatkin \& Chatterjee, 1991; Miller \& Bromiley, 1990; reliance on historical data: e.g., Gebhardt, Lee, \& Bhaskaran, 2001). The third deficiency of CAPM, the irrelevance of time horizon for implicit discount rates in equity valuation, is one of long standing (e.g., Abarbanell \& Bernard, 2000; Jensen, 1986, 1989; Marsh, 1990; Miles, 1993; Porter, 1992, 1993; Satchell \& Damant, 1995; Woolridge, 1988). Garrod and Valentincic (2004) argue that, historically, interest has focused on whether security markets are myopic with regard to earnings, thus forcing companies to 
invest only in short-term returns. This phenomenon has also been labeled short-termism-that is, excess discounting of expected cash flows that accrue further in the future (Miles, 1995).

With regard to the valuation of investment projects, Merton (1973) presents an intertemporal asset pricing model underlining the necessity to further study the impact of time horizon on consumption and investment behavior. Keane (1978) finds that the discount rate for a given investment depends on the investment's duration in addition to its riskiness. Similarly, Stein (1996) posits that managerial time horizon affects the cost of equity capital of firms. Other scholars have specifically analyzed the market risk premium $\left(\mu_{m}-i\right)$ in CAPM, with $\mu_{\mathrm{m}}$ being the return of a market portfolio and $i$ the risk-free interest rate. Lettau and Ludvigson (2002) present evidence that a large fraction of the variance in stock market returns over time needs to be attributable to movements in equity risk premia.

McNulty et al. (2002) present a way to determine term structures of equity costs. These authors state that the assumption that companies tend to settle on a discount rate and use it as their financial benchmark for long periods of time, regardless of changes that may take place in the company (or in the markets), compounds the likelihood of error on the resulting cost of equity numbers and therefore also the selection of investment projects.

Hence, using a single term, irrespective of time horizon, may be misleading regarding the valuation and the selection of investment projects in firms with above-average time horizon.

In the present article I first examine how an extended time horizon affects the risk appetite of investors. I then focus on family firms as this type of enterprise are expected to apply a longer time horizon in their decision making (Ward, 1997). The article subsequently examines how an extended time horizon affects risk-equivalent costs of equity capital. Finally, I present two types of investment strategies for long-termoriented firms and outline how they open a space for inimitable investment strategies for this type of firm.

\section{Time Horizon and Risk Appetite of Investors}

The traditional argument within CAPM is that any investor with constant relative risk aversion and facing a random-walk world is deduced to choose rationally the same share of risky assets (e.g., equity) in his or her portfolio independent of the investor's time horizon, for example, when aged 30 as when aged 65 and almost ready to retire (Samuelson, 1969). In a test of this prediction, Hariharan, Chapman, and Domian (2000) find that a person's risk tolerance and time, measured by the time span until retirement, play no role in the composition of the risky asset.

In contrast to this finding, Gunthorpe and Levy (1994) posit that the longer the time horizon, the larger the proportion of "safe" assets that should be included in a portfolio-even if returns are independent and stationary.

Both of these arguments find theoretical and some empirical evidence. However, these findings stand in contrast to the argument that a longhorizon investor can buy a larger share of equity since the law of large numbers assures that the riskiness is bound to cancel out over many years so that equities in the end will outperform lowyield safe securities (Samuelson, 1994). Additionally, the assertion that the composition of risky assets should be the same for all investors stands in strong contrast to real life, where financial advisors propose that more risk-adverse investors should hold a higher ratio of bonds to stocks (Canner, Mankiw, \& Weil, 1997).

McNulty et al. (2002) report analytical evidence from options theory (Hull, 2003) and trading experience showing that the marginal risk of an investment declines as a function of the square root of time. An example helps in understanding the relation between time horizon and the annualized risk of an investment. Imagine a venture that asks for an initial investment of 100. The project has an expected positive drift per annum of 20 , the standard deviation is 10 .

Under the condition of normal distribution of results, at the end of one year, the project will have a mean of 120 and a standard deviation of 10. At 
the end of 5 years, an average employment period of a manager in a publicly quoted firm in North America or Europe (Booz Allen Hamilton, 2005), the project is expected to have a mean of $200(=100+5 * 20)$ and a standard deviation of $10 * \sqrt{5}=22.36$. The normalized per-annum risk of the investment is therefore $4.47(=22.36 / 5)$. Taking the investment horizon of a long-termoriented firm, for example, a family firm, that plans for one whole generation, let us assume 25 years, the situation looks different. At the end of 25 years, the investment is expected be worth $600(=100+25 * 20)$ with a standard deviation of $10 * \sqrt{25}=50$. However, the normalized perannum risk of the investment has fallen to $2(=50 / 25)$.

The overall riskiness of the longer-term investment is certainly greater than that of the shorter one: 25 years of 2 is bigger than 5 years of 4.47 . However, the riskiness increases at a declining rate over time.

Samuelson $(1989,1994)$ presents further evidence that time horizon might shift portfolio proportions and that real-life investors are more risk averse than max $\mathrm{E}(\log \mathrm{W})$ - the Bernoulli case-in which time horizon does not matter at all. Samuelson $(1989,1994)$ argues that individuals are anxious not to fall below a subsistence level and insist on a minimum consumption or income level, which must be maintained at any time. This is a reasonable assumption whenever an investor has to make up a living out of his or her portfolio (e.g., via a pension plan). Hence, assuming that the investor strives to achieve a minimum subsistence income $\bar{C}$ at any time, the investor's rationale is to maximize $\int \log \left(C_{t}-\bar{C}\right) d_{t}$ (Samuelson, 1994). Then the funds the investor must put into safe nonequities diminishes as the time horizon grows.

Samuelson (1994) provides a further argument rooted in the paramount importance of a minimum attainment $\bar{C}$. Individuals tend to maximize $\mathrm{U}=\log (\mathrm{C}-\bar{C})$, with $\bar{C}>0$. In that case, if at age $(65-T)$ the investor's initial $C^{0}$ exceeds $\bar{C} /(1+\mathrm{r})^{\mathrm{T}}$, where $r$ is the risk-free interest rate, the investor will put $\bar{C} /(1+r)^{\mathrm{T}}=\mathrm{S}_{\mathrm{T}}$ in the risk-free sinking fund. The rest is invested in stocks to a fixed fraction, as set out by Bernoulli. When $T$ is large, the nonequity total $S_{\mathrm{T}}$ becomes small and hence the fraction of the investor's wealth that can be put in the risky asset rises.

In sum, there is strong theoretical, empirical, and practical evidence supporting the case of increased risk appetite for investors with longertime horizons (Canner et al., 1997; McNulty et al., 2002; Samuelson, 1989, 1994).

\section{The Case of Family Firms}

The preceding section presented evidence that the risk appetite of investors is positively affected by their time horizon. The following paragraph will first investigate the time horizon applied by family firms since this type of firm is often said to apply a longer time horizon in their decision making (Ward, 1997). Subsequently, I will investigate how this affects risk-equivalent costs of equity capital of family firms.

\section{Time Horizon of Family Firms}

There is evidence that family firms apply longer time horizons in their decision making. First, family firms often try to pass their firms on to the next generation (Ward, 1997) and often display strongly committed shareholders providing patient capital (Dobrzynski, 1993; Teece, 1992; Ward, 1991), which is capital without threat of liquidation in the short run. Studies on time horizon and the riskiness of an investment portfolio of individuals outlined above (e.g., Samuelson, 1994) limit their analysis to (65 - age) years. However, given the fact that family firms often strive for an entrepreneurial legacy that spans generations (Cruz, Nordqvist, Habbershon, Salvato, \& Zellweger, 2006), time horizon is not necessarily limited to the life span of one individual but is potentially extended by the presence of a succeeding generation that will take over the firm. In line with this argument, Walsh and Seward (1990) find that in family firms managers are also interested in firm performance beyond their working life.

Second, several studies find that CEO tenure in family firms is longer than in their nonfamily counterparts. For example, Tsai, Hung, Kuo, and 
Kuo (2006) show that for Taiwanese firms CEO turnover is significantly lower in family firms. The MassMutual American Family Business Survey (2002) reports that CEO tenure at a familyowned business is as much as six times longer than at a typical nonfamily public company. As the assessment of personal risk in the business context is influenced by the time horizon a manager has (Bernstein, 1996), nonfamily executives in northern America and Europe with an average investment horizon of 5 years (Booz Allen Hamilton, 2005) are unqualified to tackle investment opportunities that take years to show success. For this reason, altering, for example, extending, the time horizon to more than 5 years, as observed with family managers (see above), shifts the investment preferences and strategic choices of firms.

Third, cyclical industries with widely fluctuating prices are expected to be unattractive to short-term-oriented investors. In contrast, cyclical industries can be an interesting playing field for long-term-oriented (family) firms (Aronoff \& Ward, 1991). Often, these businesses are considered out of favor, to be avoided. However, there seems to be a natural fit between the resource configurations of family firms (Sirmon \& Hitt, 2003), like patient capital, and the specific requirements of the industry and the investment.

I therefore investigate whether family firms are more present in cyclical industries compared to noncyclical industries, which is considered as a further proof for a longer time horizon in family firms since the business cycles in this type of business make market entrance for short-term investors unattractive. I tested this hypothesis on the stocks included in the Dow Jones STOXX 600 industry indices. This family of indices includes 600 European enterprises within 18 industries. To determine whether the firms included in the different industries could be considered as family firms, the data set by Faccio and Lang (2002) was consulted, which provides insight into the ultimate ownership of western European corporations. Whenever a firm in the Dow Jones STOXX 600 was not considered in the data set by Faccio and Lang (2002), the firm was excluded from the analysis. In total, 510 European firms were considered in the present investigation.

The cyclical tendency of an industry is measured by the correlation between the output growth of an industry and the aggregate output growth (Boudoukh, Richardson, \& Whitelaw, 1994). These correlation data were retrieved from Boudoukh et al. (1994), Berman and Pfleeger (1997), and Hornstein (2000).

The share of family firms within each industry and the data on the cyclical tendency of the different industries were then merged. The results are displayed in Table 1.

The graphical depiction of Table 1 in Figure 1 shows the positive relation between the cyclical tendency of an industry and the presence of family firms within it.

As hypothesized, the share of family firms within an industry increases with growing correlation between the output growth of an industry and the aggregate output growth, for example, the cyclical tendency of an industry.

Hence, due to the predominance of the business goal to pass on the firm to heirs, due to longer CEO tenure and the resulting investment preferences, and the presence of family firms in cyclical industries, I present evidence that family firms tend to have a longer time horizon in their business activities and investment choices in contrast to most nonfamily enterprises.

\section{Costs of Equity Capital of Family Firms}

Costs of equity capital compensate investors for the equity risk they bear (Lubatkin, Schulze, McNulty, \& Yeh, 2003). Given that family firms display an extended time horizon and given that the marginal risk of an investment declines over time, the question is raised of how costs of equity capital are affected by the increased time horizon, as observed with family firms.

For example, De Visscher, Aronoff, and Ward (1995) proposed a revised version of CAPM for family firms that adapts the cost of equity capital formula within CAPM for an illiquidity premium (IP) and a family effect (FE). Family effect is introduced in CAPM by multiplying the traditional 
Table 1 Share of Family Firms and Cyclical Tendency of Different Industries

\begin{tabular}{lccc}
\hline Industry & $N$ & $\begin{array}{c}\text { Share of family firms } \\
\text { within industry group }\end{array}$ & $\begin{array}{c}\text { Correlation between industry output } \\
\text { and aggregate economic output }\end{array}$ \\
& & $\begin{array}{c}\text { Source: DJ STOXX 600; } \\
\text { Faccio and Lang, 2002 }\end{array}$ & $\begin{array}{l}\text { Source: Boudoukh et al., 1994; } \\
\text { Berman and Pfleeger, 1997; } \\
\text { Hornstein, 2000 }\end{array}$ \\
& & & 0.03 \\
\hline Banks & 68 & $0.0 \%$ & -0.17 \\
2 Insurance & 35 & $0.0 \%$ & 0.11 \\
3 Telecommunication & 20 & $0.0 \%$ & 0.16 \\
4 Utilities & 32 & $0.0 \%$ & -0.07 \\
5 Basic resources & 17 & $5.9 \%$ & -0.1 \\
6 Oil and gas & 14 & $7.1 \%$ & 0.03 \\
7 Financial services & 35 & $17.1 \%$ & 0.17 \\
8 Industrial Goods and Services & 61 & $19.7 \%$ & 0.39 \\
9 Food and Beverage & 19 & $21.1 \%$ & 0.43 \\
10 Media & 28 & $21.4 \%$ & 0.16 \\
11 Health Care & 25 & $24.0 \%$ & 0.74 \\
12 Travel and Leisure & 24 & $25.0 \%$ & 0.53 \\
13 Chemicals & 19 & $26.3 \%$ & 0.86 \\
14 Technology & 18 & $27.8 \%$ & 0.75 \\
15 Automobile & 14 & $28.6 \%$ & 0.92 \\
16 Retail & 23 & $30.4 \%$ & 0.89 \\
17 Construction and material & 28 & $35.7 \%$ & 0.93 \\
18 Personal and household goods & 30 & $36.7 \%$ & \\
& & & \\
& & &
\end{tabular}

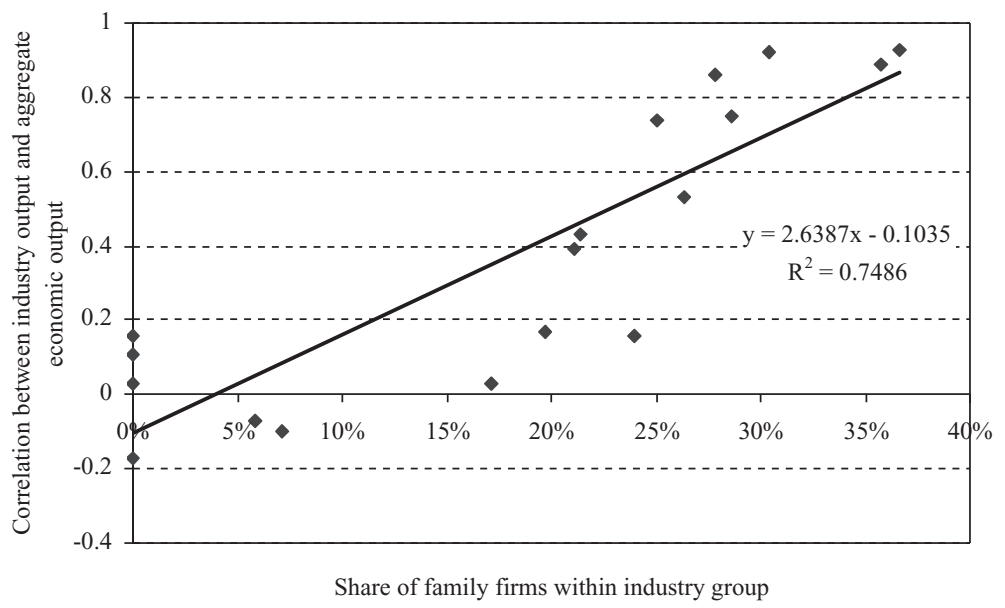

Figure 1 Relation Between the Cyclical Tendency of an Industry and the Presence of Family Firms.

Source: Dow Jones STOXX 600; Faccio and Lang (2002); Boudoukh et al. (1994); Berman and Pfleeger (1997); Hornstein (2000). 
form of cost of equity as determined by CAPM with (1-FE). FE can range from 0 for a contentious, restless, or litigious group to 1 for a family that is perfectly dedicated. However, De Visscher et al. (1995) themselves note that the term "family effect" is problematic, especially if a family is perfectly dedicated. In this case, FE and, therefore, cost of equity would approach 0 . Even though McConaughy (1999) proposes that (1-FE) should be replaced by (FE), this does not solve the central shortcomings of CAPM outlined above.

Adams, Manners, Astrachan, and Mazzola (2004) investigate the issue of cost of equity capital in family firms by answering the question of under which conditions profit implies adequate return. According to Adams et al. (2004), it is the private family firm leaders' own aspirations for growth and payout that determine an adequate cost of equity capital. The views of Adams et al. (2004), considering that cost of equity capital are in part discretionary, challenge the view of traditional finance researchers who argue that firms, which invest at lower returns than required for an investment with a comparable risk/return profile, will maneuver themselves out of the market and will disappear in the long run. In addition, these traditional finance researchers would argue that underperforming investments would increase the pressure on family shareholders to allocate their money in the capital market at higher returns.

Given the fact that for many family firms the family is the most important source of (equity) funding (Achleitner \& Poech, 2004) and as family managers often follow nonmonetary goals (Sharma, Chrisman, \& Chua, 1997; Ward, 1997), the view of Adams et al. (2004) deserves further attention. If the cost of equity capital can be determined by the owners, depending on their requirements, subjective needs, and preferences, family shareholders are free to substitute monetary for nonmonetary returns (e.g., independence, employment for family members, prestige) and accept lower monetary returns on the equity capital they invest. Zellweger (2006) presents evidence that when a company is not for sale (as in most family firms for which the continuation of the firm is the predominant goal), entrepreneurs tend to value emotional factors and substitute them for monetary outcomes. Ehrhardt and Nowak (2003) present evidence that majority shareholders earn private benefits of control, for example, in the form of social prestige.

There is further empirical evidence that privately held family firms indeed apply lower costs of equity capital. Poutziouris (2001) finds, for example, that privately owned family firms strongly stick to the pecking order of financing. With this result, Poutziouris (2001) implicitly provides evidence for the argument that family firms prefer family and firm internal equity financing as it is the cheapest source of capital.

The above literature about cost of equity capital of family firms sheds light on some aspects of the costs of equity capital of family firms. However, the literature has not taken into consideration the differing time horizon of family firms and how this might affect the costs of equity capital for this type of firm.

The impact of time horizon on costs of equity capital has been studied by many researchers. For example, Lubatkin et al. (2003) report that even minor changes in the time period used can cause more than $100 \%$ variance in beta estimate. Graham and Harvey (2003) find that market risk premium varies with time horizon of the investment. McNulty et al. (2002) argue that given that the marginal risk of an investment declines as a function of the square root of time, as outlined above (Hull, 2003), the falling marginal risk serves to reduce the annual discount rate-the costs of equity capital.

Hence, if investors set a company's cost of equity capital to the rate of return that will insure investors against the risk that they may suffer a loss (Lubatkin et al., 2003), the costs of equity capital need to fall with increasing holding period. McNulty et al. (2002) argue that since the annual risk of an investment falls at the square root of time (Figure 2), the costs of equity capital serves to reduce the costs of equity for this type of firm.

Similarly, Taleb (2001) outlines that over a relatively brief period of time, return increases pro- 


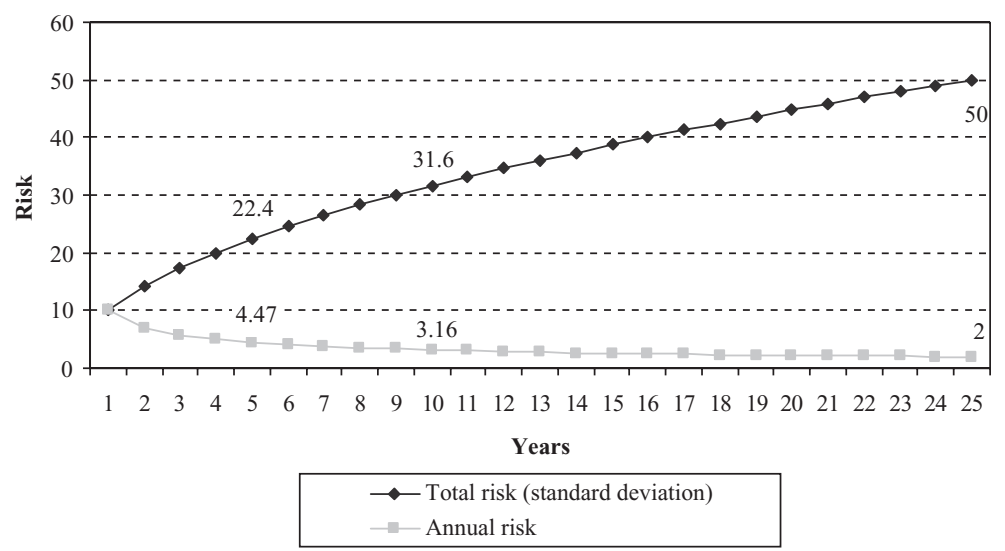

Figure 2 Normalized Annual Risk and Investment Horizon for an Investment With a Standard Deviation of $10 \%$.

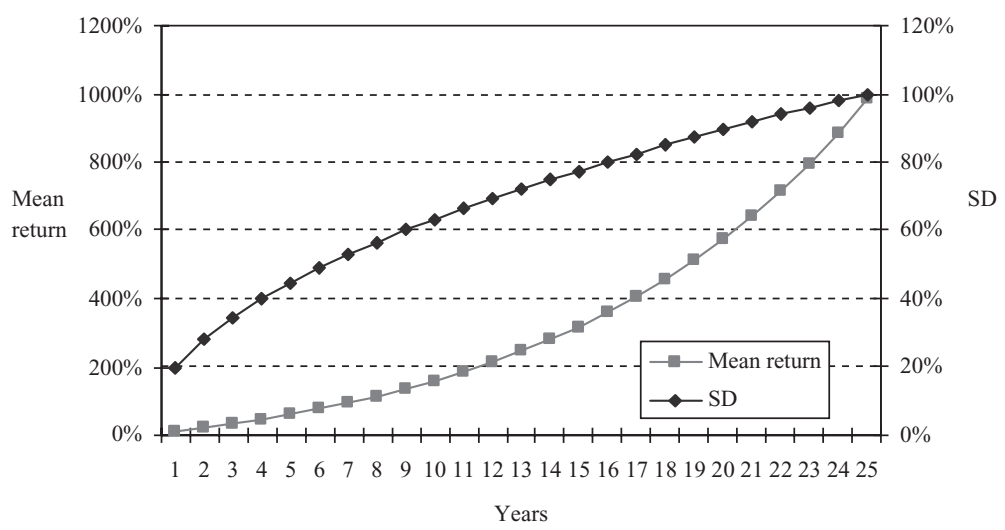

Figure 3 Mean Return and Standard Deviation With Increasing Time Horizon for an Investment With Annualized Return of $10 \%$ and a Standard Deviation of $20 \%$. $S D=$ Standard deviation .

portionally with time, but risk increases more slowly at the square root of time (Figure 3 ). This means that the risk/reward ratio becomes increasingly favorable over long time horizons. Figure 4 illustrates this finding for an investment with an annualized return of $10 \%$ and a standard deviation of $20 \%$.

In sum the text presents three arguments supporting the case of lower costs of equity in family firms. First, family firms display partly discretionary costs of equity capital that provide this type of shareholder with the possibility of substituting monetary for nonmonetary returns of their activity (Adams et al., 2004; Zellweger, 2006). Second, the finding that family firms strongly stick to the pecking order of financing provides further evidence for the case of cheap equity financing in family firms (Poutziouris, 2001). And third, the extended time horizon of family firms serves to reduce the marginal risk of an investment and therefore the corresponding risk-equivalent costs of equity capital (McNulty et al., 2002). The above considerations lead to the following proposition. 


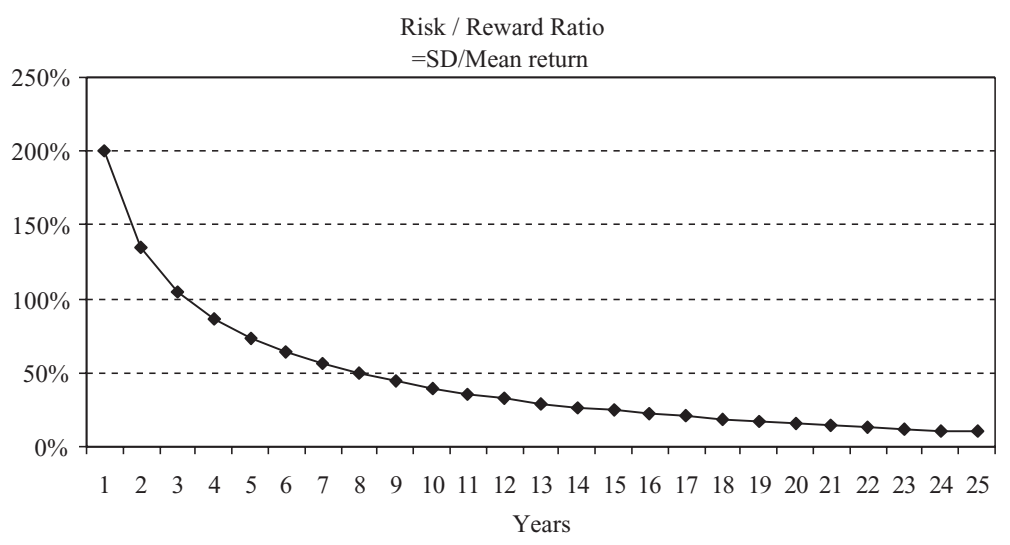

Figure 4 Risk/Reward Ratio With Increasing Holding Period for an Investment With Annualized Return of $10 \%$ and a Standard Deviation of $20 \%$.

$S D=$ Standard deviation.

Proposition 1. All other things being equal firms with an above-average time horizon (e.g., family firms) can apply lower costs of equity numbers than can more short-term-oriented firms (e.g., nonfamily firms).

\section{Cost of Equity Capital and Economic Value Created by Investment Projects}

Copeland et al. (2000) state that a company creates value by investing capital at rates that exceed its cost of capital. As introduced above, applying a cost of capital lower than required in an efficient market environment for anonymous investors is expected to have important consequences for the investment behavior of firms. In particular, if a company routinely applies too high a cost of capital in its project valuations, it will reject valuable opportunities, which its competitors will happily seize. Setting the rate too low, on the other hand, the company will commit resources to projects that will erode profitability and destroy shareholder value (McNulty et al., 2002). The finding that family firms tend to apply lower costs of equity capital therefore raises the question of whether family firms systematically underinvest by seizing insufficiently profitable projects and thereby endanger their survival in the long run.
This argument stands in contrast to the wide presence and the financial success of family firms in economies throughout the world as privately owned and publicly quoted enterprises (e.g., Jaskiewicz, Klein, \& Schiereck, 2005). The answer to this dilemma should, however, not only respect cost of equity capital as the hurdle rate of the investment selection but also needs to include the rates of return on the investments undertaken just as the opportunities associated with having lower costs of equity capital than competitors.

In line with Copeland et al. (2000), the present text argues that companies create shareholder value by investing their capital at rates of return that exceed their costs of equity capital. Hence, whether shareholder value is created or destroyed is determined by the risk premium, defined as the difference between the return of the project $i$ and the associated costs for the equity capital to finance it, $\left(\mu_{\mathrm{i}}-\mathrm{c}_{\mathrm{i}}\right)$, and not solely the absolute rate of return of a project.

Considering the risk premium between the project's return and the associated risk, it becomes evident that with the cost of equity capital being lower, the return of the investment project can be lower as well. In the end, whether the investment project of the long-term-oriented firm or the one of the short-term-oriented firm 
creates more shareholder value depends on the risk premia they earn (Figure 4).

Due to above considerations, long-termoriented firms, for example, family firms, are able to invest in projects that seem less or insufficiently attractive to short-term-oriented firms, for example, nonfamily firms, while still creating as much shareholder value as their nonfamily counterparts. In addition, this helps to build unique investment and business strategies that are just as valuable as those of short-term-oriented firms.

\section{Generic Investment Strategies of Family Firms}

In line with above considerations, risk premia similar to those of the short-term-oriented investor, combined with the extended planning horizon, enable long-term-oriented firms to follow unique and hardly inimitable investment strategies. These strategies can be built in two generic directions, based on the consideration that costs of equity capital need to reflect the risk of an investment (Lubatkin et al., 2003), and given the fact that the marginal risk of the investment is falling at $\sigma * \sqrt{\mathrm{t}}$.

First, because the marginal risk of the investment is falling over time, long-term-oriented firms can invest in projects with equal risk but lower returns compared to the short-term investor.

Second, given the fact that the risk of the investment is falling over time, long-term-oriented firms can invest in projects with equal returns but higher risk compared to the short-term investor.

The two following subsections discuss the generic investment strategies of long-termoriented firms, for example, family firms, in more detail.

\section{Generic Investment Strategy 1: The Perseverance Strategy}

In the first generic investment strategy, longterm-oriented firms seize investment projects with equal risk but lower return compared to the investments of short-term-oriented firms. The longer planning horizon gives this type of firm the possibility of accepting projects with lower returns than can their nonfamily counterparts.

In practice, this means that long-term-oriented firms can seize investment opportunities their more short-term-oriented-high cost of equity capital-competitors do not consider as sufficiently attractive. At first sight, developing such projects seems unattractive; however, such a situation offers long-term-oriented firms the possibility of developing their activities unhindered by aggressive competitors and of conquering markets that competitors cannot enter.

There are many examples of family firms who follow the perseverance strategy. Aronoff and Ward (1991) find that family firms are often active in industries with widely fluctuating prices, as are trading businesses such as scrap, commodities, or shipping companies. For example, the noble Thurn und Taxis family is one of the largest private land and forestry developers in Germany and has been developing its business activities for several centuries. As the returns are low in this type of business, such an investment is particularly suited to long-term-oriented enterprises as family firms.

Consequently, long-term-oriented firms are recommended to look for investment projects that fall slightly "below the radar" of more short-termoriented competitors in terms of the expected returns of the projects.

Proposition 2. Long-term-oriented firms (e.g., family firms) can invest in lower-return projects than can more short-term-oriented competitors (e.g., nonfamily firms) and create just as much shareholder value as the more short-term-oriented firms.

\section{Generic Investment Strategy 2: The Outpacing Strategy}

The second generic investment strategy comprises the situation in which family firms seize investment projects with equal return compared to the investments of nonfamily firms. The longer planning horizon gives family firms the possibility of 
accepting riskier investment projects than their nonfamily counterparts. This proposition is based on three considerations.

First, under the assumption that costs of equity capital need to reflect the risk of an investment and given the fact that the marginal risk of the investment is lowering at the square root of time, as outlined above, the long-term-oriented firm can take on projects with a higher standard deviation in comparison to the more short-termoriented firm.

Second, as outlined above, there is evidence that real-life investors are more risk averse than max E $(\log W)$ - the Bernoulli case - in which time horizon does not matter at all (Samuelson, 1989, 1994). As outlined above, Samuelson (1994) proposes that individuals tend to maximize $\mathrm{U}=\log (\mathrm{C}-\bar{C})$, with $\bar{C}>0$ being an individual's minimum attainment. The Samuelson (1994) model, which states that at age $(65-T)$ the investor will put $\bar{C} /(1+\mathrm{r})^{\mathrm{T}}=\mathrm{S}_{\mathrm{T}}$ in the risk-free sinking fund and the rest in stocks to a fixed fraction, can be extended for family firms. The investment horizon of this type of firm is not limited to the working life of an individual but can last longer, given that the subsequent family generation might be able to profit from the investment of the preceding generation. As family principals (e.g., parents) often display altruistic feelings for family agents (e.g., children) (Schulze, Lubatkin, \& Dino, 2003), the time horizon of a family investor can be extended to $\mathrm{T}_{\text {tota }}=\mathrm{T}_{\text {parent }}+\mathrm{T}_{\text {child. }}$. Consequently, $\bar{C} /(1+r)^{\mathrm{T} \text { total }}=S_{\mathrm{T}}$ total is falling and the fraction of the investor's wealth that can be put in the risky equity asset rises.

Third, extending the arguments of Bodie, Merton, and Samuelson (1992), who posit that investors can vary their work effort to assure their minimum consumption, it can be concluded that investors who are willing to lower their $\bar{C}$ (e.g., due to substitutional effects between monetary and nonmonetary outcome preferences as observed in family firms) (Adams et al., 2004; Zellweger, 2006) can increase the riskiness of their investment strategies by plugging in high mean-high variance equities because, if luck turns bad, the investor can adapt the minimum consumption level.
Just as for the perseverance strategy, there are well-known examples for the outpacing strategy. The Swiss Bertarelli family owns the world's third largest biotechnology firm, Serono. The family controls $71.54 \%$ of the publicly quoted equity. Serono is active in the pharmaceutical industry, in which new medicaments and active substances take years to bring to market and a flop in one product can cause the default of the company. Serono has managed to be successful throughout the world with only seven products.

Consequently, with the outpacing strategy, longterm-oriented firms are recommended to invest in riskier projects with equal return in comparison to their short-term-oriented competitors. Given the long-term horizon that can go beyond the working life of an individual and the possibility of adapting the minimum consumption level depending on the success of the firm, the firm is able to seize higher risk projects than its competitors.

Proposition 3. Long-term-oriented firms (e.g., family firms) can invest in riskier projects than can more short-term-oriented competitors (e.g., nonfamily firms) and create just as much shareholder value as the more short-term-oriented firms.

\section{The Family Business Playing Field}

As shown above, a longer time horizon and the resulting lower costs of equity capital give rise to two generic investment strategies. First, equalrisk investments allow family firms to accept investment opportunities with lower returns (perseverance strategy). Second, equal-return projects allow retaining investment opportunities with higher risk (outpacing strategy). Hence, family firms are able to tackle investment opportunities that can be characterized as displayed in Figure 6.

The two generic investment strategies indicated above open a space for investment opportunities characterized by combinations of higher risk and lower return that need to satisfy the condition that $r_{s}-c_{s} \leq r_{1}-c_{1}$, assuring that the long-termoriented firm creates as much value as the more short-term-oriented firm does (Figure 5). 


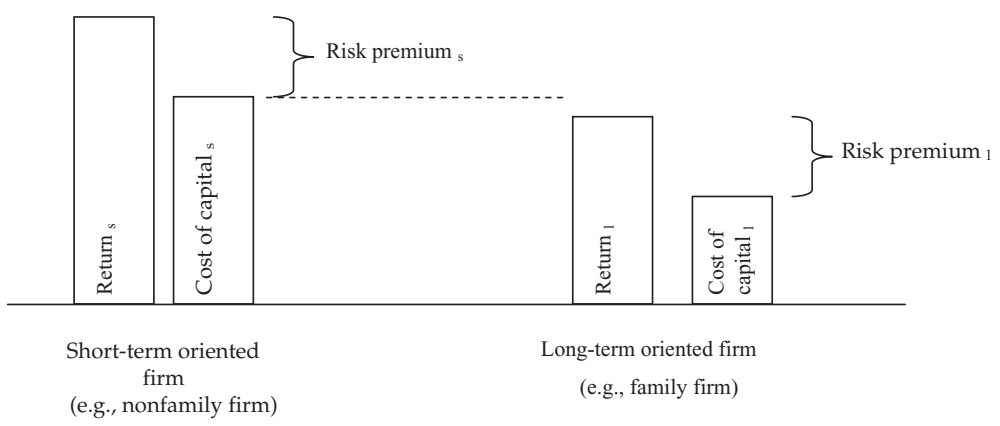

Figure 5 Risk Premia of Long- and Short-Term-Oriented Firms. I = long-term; s = short-term.

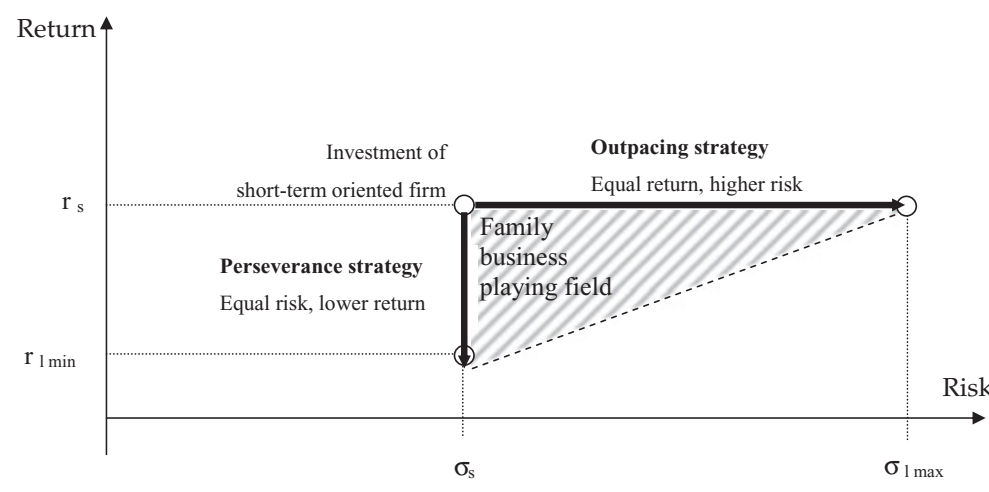

$\mathrm{r}=$ annual return of the project; $\sigma=$ annual risk of the investment; $1=$ long-term; $\mathrm{s}=$ short-term.

Figure 6 Generic Investment Strategies for Long-Term-Oriented Firms.

$r=$ annual return of the project; $\sigma=$ annual risk of the investment; I = long-term; $s=$ short-term.

The family business playing field sets the limits for the generic investment strategies. The size of $r_{I \min }$ and $\sigma_{I \max }$ and hence the size of the family business playing field depends on the assumption regarding the relation between time horizon, respectively, marginal risk of an investment and costs of equity capital.

\section{Strategic Implications}

An important aspect of many managers' jobs is making investment decisions that will affect cash flows in multiple future periods (Rogerson, 1997). Since managerial compensation is typically based on accounting income (Antle \& Smith, 1986;
Lambert \& Larcker, 1987; Rosen, 1992), managers can generally affect their future compensation by altering investment levels. Lazonick (1994) argues that pressured by the financial community, industrial managers favor investment strategies that make use of productive resources that have already been developed, and hence can generate earnings immediately without incurring large capital outlays.

The natural question that arises in this context is whether managers' private incentives to choose investment levels result in efficient investment levels from the perspective of shareholders. A frequently expressed concern is that managers may be too impatient and thus may underinvest rela- 
tive to the efficient level, either because their perceived personal cost of capital is higher than the firm's or because they have a shorter time horizon than the firm (i.e., they plan to leave or retire before all the benefits of the investment are realized) (Rogerson, 1997).

Hence, a firm that is able to establish a time horizon that reaches beyond that of its competitors is less likely to be affected by this shorttermism. The longer planning horizon gives this type of firm the possibility of lowering their costs of capital and, in turn, accepting lower meanhigher variance projects. Although this may seem counterintuitive, it can lead to strategic advantages through the following effects.

First, due to lower costs of equity capital, the long-term-oriented firm will be able to take on more projects. Consequently, the pool of projects the long-term-oriented firm can develop is larger compared to the one of a high cost-of-equitycapital firm. The larger project pool will give the long-term/low-cost-of-equity-capital type of firm a larger number options, from which the best performing projects can be selected and further developed when the uncertainty about the projects' outcomes decreases with time.

Second, taking on more projects may result in a larger diversification for this type of firm. Wimmer, Domayer, Oswald, and Vater (2005, p. 123), for example, find that large multigenerational family firms often display very diversified product portfolios that help reduce the dependence on the success of one single product or technology. Hence, larger project portfolios may help diversify the investment risks across the firm.

Hence, whereas at first sight the generic investment strategies lead to a seemingly unattractive investment portfolio, in the long run they can lead to a competitive advantage over more short-termoriented firms.

\section{Conclusion and Limitations}

Certain scholars who argue that high concentration of ownership can result in risk-averse strategic behavior (Chandler, 1990), a preference for projects with short pay-back periods (Chen, 1995), and a tendency toward underinvestment (Fama \& Jensen, 1985) have overlooked the opportunities associated with long-term investment strategies enabled by strong long-termoriented shareholders like, for example, family shareholders.

The considerations on generic investment strategies based on the lower cost of equity capital, however, show that family firms have good reasons to invest in long-term projects without risk of underinvestment. The generic investment strategies challenge the conventional belief that firms should try to maximize return or minimize risk in every situation. For long-term-oriented firms, it can be rational to seek investment projects that are more risky and/or less profitable than the projects of their more short-termoriented competitors. Just as Eaton, Yuan, and Wu (2002) concluded, lower (agency) costs of capital could lead to a competitive advantage.

It seems important to note that the above considerations on time horizon and generic investment strategies are not limited to family firms. The strategic options outlined above are open also to nonfamily firms that are able to establish a long-term horizon in their investing.

There is a limitation to the argument that by extending the planning horizon, the associated cost of capital can be lowered. In fact, with an infinite planning horizon, the normalized annual risk would fall to zero, which is not possible given the fact that along with the normalized annual risk, the project also bears some instantaneous default risk (Duffee, 1999). A long-term strategy therefore needs to consider the instantaneous default risk that could arise from one period to the next, even though the normalized annual risk falls with the longer planning horizon.

One of the main arguments put forward in this article is that an increasing time horizon reduces the marginal riskiness of an investment and hence the risk-equivalent cost of equity capital. At this stage it remains open how time affects costs of equity capital in a CAPM world. The applicability and the extent to which the perseverance and the outpacing strategies can be put into practice (e.g., 
the delimitation of the family business playing field, $r_{\operatorname{lmin}}$ and $\sigma_{l \max }$ ) depend on the exact specification of the relation between costs of equity capital and time horizon.

Therefore, the above considerations call for an adapted form of asset pricing model that fits the needs of firms with particular planning horizons. In line with the opportunities and threats of the generic investment strategies outlined above, such a model needs to consider two elements: first, just as with interest rates on debt, it should take into account the time horizon when calculating rates of return on equity; second, it should be able to allow for a minimum consumption or subsistence level that the investor requires at all times, which can differ depending on the needs of the investor.

The present article sheds light on specific business strategies for family firms. The above investigation provides an answer to Chrisman, Chua, and Sharma's (2005) question about whether family firms have the same strategic alternatives as nonfamily firms. The present article is complementary to the existing literature on the basis of competitive advantages of family firms that has either stressed the systems of corporate governance (Carney, 2005) or the resources and abilities a family is able to provide to its firm (distinctive familiness) (Habbershon, Williams, \& MacMillan, 2003). In line with the arguments by Miller and Le-Breton-Miller (2005), the present article argues that a long-term investment horizon is a further source of competitive advantage for this type of firm.

\section{References}

Abarbanell, J., \& Bernard, V. (2000). Is the U.S. stock market myopic? Journal of Accounting Research, 38(2), 221-242.

Achleitner, A. K., \& Poech, A. (2004). Familienunternehmen und Private Equity: Die psychologischen Bruchstellen. Munich: Apax Partners.

Adams, A. F. III, Manners, G. E., Astrachan, J. H., \& Mazzola, P. (2004). The importance of integrated goal setting: The application of cost-of-capital concepts to private firms. Family Business Review, 17(4), 287-302.
Antle, R., \& Smith, A. (1986). An empirical investigation of the relative performance evaluation of corporate executives. Journal of Accounting Research, 24, 1-39.

Aronoff, C. E., \& Ward, J. L. (1991). Family business source book. Detroit, MI: Omnigraphs.

Berman, J., \& Pfleeger, J. (1997). Which industries are sensitive to business cycles? Monthly Labor Review, February, 19-25.

Bernstein, P. L. (1996). Against the gods: The remarkable story of risk. New York: John Wiley \& Sons.

Black, F. (1972). Capital market equilibrium with restricted borrowing. Journal of Business, 45, 444-455.

Bodie, Z., Merton, R. C., \& Samuelson, W. F. (1992). Labor supply flexibility and portfolio choice in a life cycle model. Journal of Economic Dynamics and Control, 16, 427-449.

Booz Allen Hamilton. (2005). CEO succession 2004: The world's most prominent temp workers. Strategy + Business, 39, 28-43.

Boudoukh, J., Richardson, M., \& Whitelaw, R. F. (1994). Industry returns and the Fisher effect. Journal of Finance, 49(5), 1595-1615.

Cannella, A. A., Jr., \& Lubatkin, M. (1993). Succession as a sociopolitical process: Internal impediments to outsider selection. Academy of Management Journal, 36, 763-793.

Canner, N., Mankiw, N. G., \& Weil, D. N. (1997). An asset allocation puzzle. American Economic Review, March, 181-191.

Carney, M. (2005). Corporate governance and competitive advantage in family-controlled firms. Entrepreneurship Theory and Practice, 29(3), 249-265.

Chandler, A. D. (1990). Scale and scope. Cambridge, MA: Cambridge University Press.

Chatterjee, S., Lubatkin, M. H., \& Schulze, W. S. (1999). Toward a strategic theory of risk premium: Moving beyond CAPM. Academy of Management Review, 24(3), 556-567.

Chen, M. (1995). Asian management systems: Chinese, Japanese and Korean styles of business. London: Routledge.

Chrisman, J. J., Chua, J. H., \& Sharma, P. (2005). Trends and directions in the development of a strategic management theory of the family firm. Entrepreneurship Theory and Practice, 29(5), 555-575.

Copeland, T., Koller, T., \& Murrin, J. (2000). Valuation. New York: John Wiley \& Sons.

Cruz, C., Nordqvist, M., Habbershon, T., Salvato, C., \& Zellweger, T. (2006). A conceptual model of transgenerational entrepreneurship in family influenced firms. Jväskilä: International Family Enterprise Research Academy. 
De Visscher, F. M., Aronoff, C. E., \& Ward, J. L. (1995). Financing transitions: Managing capital and liquidity in the family business. Family Business Leadership Series 7. Marietta, GA: Family Enterprise Publishers.

Dobrzynski, J. H. (1993). Relationship investing, Business Week, 3309, 68-75.

Duffee, G. R. (1999). Estimating the price of default risk. Review of Financial Studies, 12(1), 197-226.

Eaton, C., Yuan, L., \& Wu, Z. (2002). Reciprocal altruism and the theory of the family firm. Paper presented at the Second Annual Conference on Theories of the Family Enterprise: Search for a Paradigm. Philadelphia, PA.

Ehrhardt, O., \& Nowak, E. (2003). Private benefits and minority shareholder expropriation (or what exactly are private benefits of control?) CFS Working Paper Series. Paper presented at the EFA annual conference.

Faccio, M., \& Lang, L. (2002). The ultimate ownership of western European corporations. Journal of Financial Economics, 65, 365-395.

Fama, E. F., \& Jensen, M. C. (1985). Organizational forms and investment decisions. Journal of Financial Economics, 14, 101-119.

Garrod, N., \& Valentincic, A. (2004). The term structure of implicit discount rates in security valuation. Journal of Business Finance \& Accounting, 32(7\&8), 1237-1274.

Gebhardt, W. R., Lee, C. M. C., \& Bhaskaran, S. (2001). Toward an implied cost of capital. Journal of Accounting Research, 39(4), 135-176.

Graham, J. R., \& Harvey, C. R. (2003). Expectations of equity risk premia, volatility and asymmetry. Working paper. Fuqua School of Business.

Gunthorpe, D., \& Levy, H. (1994). Portfolio composition and the investment horizon. Financial Analysts Journal January-February, 51-56.

Habbershon, T. G., Williams, M., \& MacMillan, I. C. (2003). A unified system perspective of family firm performance. Journal of Business Venturing, 18, 451465.

Hariharan, G., Chapman, K. S., \& Domian, D. L. (2000). Risk tolerance and asset allocation for investors nearing retirement. Financial Services Review, 9, 159170.

Hornstein, A. (2000). The business cycle and industry comovement, Economic Quarterly, 86(1), 27-48.

Hull, J. (2003). Options, futures and other derivatives, 5 th ed. Upper Saddle River, NJ: Prentice Hall.

Jaskiewicz, P., Klein, S., \& Schiereck, D. (2005). Family influence and performance-theoretical concepts and empirical results. Working paper. European Business School.
Jensen, M. C. (1986). The takeover controversy: Analysis and evidence. Midland Corporate Finance Journal, $4(1), 6-32$.

Jensen, M. C. (1989, Sept.-Oct.). Eclipse of the public corporation. Harvard Business Review, 61-74.

Keane, S. (1978). The cost of capital as a financial decision tool. Journal of Business Finance \& Accounting, 5(3), 339-353.

Lambert, R. A., \& Larcker, D. F. (1987). An analysis of the use of accounting and market measures of performance in executive compensation contracts. Journal of Accounting Research, 25, 85-125.

Lazonick, W. (1994). Creating and extracting value: Corporate investment behavior and American economic performance. Studies in Technology, Innovation and Economic Policy (STEP). University of Oslo and University of Massachusetts Lowell.

Lettau, M., \& Ludvigson, S. (2002). Time-varying risk premia and the cost of capital: An alternative implication of the $\mathrm{Q}$ theory of investment. Journal of Monetary Economics, 49, 31-66.

Lintner, J. (1965). The valuation of risk assets and the selection of risky investments in stock portfolios and capital budgets. Review of Economics and Statistics, 47, 13-37.

Lubatkin, M., \& Chatterjee, S. (1991). The strategyshareholder value relationship: Testing temporal stability across market cycles. Strategic Management Journal, 12, 251-270.

Lubatkin, M., Schulze, W. S., McNulty, J. J., \& Yeh, D. Y. (2003). But will it raise my share price? New thoughts about an old question. Long Range Planning, 36, 81-91.

March, J. G. \& Shapira, Z. (1987). Managerial perspectives on risk and risk-taking . Management Science, 33, 1404-1418.

Marsh, P. (1990). Short termism on trial. London: Institutional Fund Managers' Association.

MassMutual American Family Business Survey. (2002). Boston: George G. and Robin Raymond Family Business Institute and Massachusetts Mutual Life Insurance Company.

McConaughy, D. (1999). Is the cost of capital different for family firms? Family Business Review, 12(4), 353359.

McNulty, J. J., Yeh, T. D., Schulze, W. S., \& Lubatkin, M. S. (2002). What's your real cost of capital? Harvard Business Review, 80(10), 114-121.

Merton, R. C. (1973). An intertemporal asset pricing model. Econometrica, 41(5), 867-887.

Miles, D. (1993). Testing for short termism in the UK stock market. Economic Journal, 103, 13791396. 
Miles, D. (1995). Testing for short termism in the UK stock market: A reply. Economic Journal, 105, 12241227.

Miller, D., \& Le-Breton-Miller, I. (2005). Managing for the long run: Lessons in competitive advantage from great family businesses. Boston, MA: Harvard Business School Press.

Miller, K., \& Bromiley, P. (1990). Strategic risk and corporate performance: An analysis of alternative risk measures. Academy of Management Journal, 33, 756779.

Mossin, J. (1966). Equilibrium in a capital asset market. Econometrica, 34, 768-783.

Porter, M. E. (1992). Capital disadvantage: America's falling capital investment system. Harvard Business Review, 70, 65-82.

Porter, M. E. (1993). Investment behaviour and time horizons in American industry. In Capital Choices. Boston, MA: Harvard Business School Press.

Poutziouris, P. (2001). The views of family companies on venture capital: Empirical evidence from the UK small to medium-size enterprising economy. Family Business Review, 14(3), 277-291.

Rogerson, W. P. (1997). Intertemporal cost allocation and managerial investment incentives: A theory explaining the use. Journal of Political Economy, 105(4), 770-796.

Rosen, S. (1992). Contracts and the market for executives. In L. Werin \& H. Wijkander (Eds.), Contract Economics. Cambridge, MA: Blackwell.

Ross, S. A. (1976). The determination of financial structure: The incentive-signaling approach. Bell Journal of Economics, 8, 23-40.

Samuelson, P. A. (1969). Lifetime portfolio selection by dynamic stochastic programming. Review of Economics and Statistics, 51(3), 239-246.

Samuelson, P. A. (1989). The judgment of economic science on rational portfolio management: Indexing; timing, and long-horizon effects. Journal of Portfolio Management, 16(1), 4-12.

Samuelson, P. A. (1994). The long-term case for equities. Journal of Portfolio Management, 21(1), 15-24.

Satchell, S. E., \& Damant, D. C. (1995). Testing for short termism in the UK stock market: A comment. Economic Journal, 105, 1218-1223.

Schulze, W. S., Lubatkin, M. H., \& Dino, R. M. (2003). Exploring the agency consequences of ownership dispersion among the directors of private family firms. Academy of Management Journal, 46(2), 179194.

Sharma, P., Chrisman, J. J., \& Chua, J. H. (1997). Strategic management of the family business: Past research and future challenges. Family Business Review, 10, $1-35$.

Sharpe, W. F. (1964). Capital asset prices: A theory of market equilibrium under conditions of risk. Journal of Finance, 19, 425-442.

Sirmon, D., \& Hitt, M. (2003). Managing resources: Linking unique resources, management, and wealth creation in family firms. Entrepreneurship Theory and Practice, 27(4), 339-358.

Stein, J. (1996). Rational capital budgeting in an irrational world. Journal of Business, 69(4), 429-455.

Taleb, N. N. (2001). Fooled by randomness. New York: Texere Publishing.

Teece, D. J. (1992). Foreign investment and technological development in Silicon Valley. California Management Review, 34(2), 88-106.

Tsai, W. H., Hung, J. H., Kuo, Y. C., \& Kuo, L. (2006). CEO tenure in Taiwanese family and nonfamily firms: An agency theory perspective. Family Business Review, 19(1), 11-28.

Walsh, J. P., \& Seward, J. K. (1990). On the efficiency of internal and external corporate control mechanisms. Academy of Management Review, 15, 421-458.

Ward, J. (1991). The power of patient capital. Nation's Business, 79(9).

Ward, J. (1997). Growing the family business: special challenges and best practices. Family Business Review, 10(4), 323-337.

Wimmer, R., Domayer, E., Oswald, M., \& Vater, G. (2005). Familienunternehmen-Auslaufmodell oder Erfolgstyp, 2nd ed. Wiesbaden: Gabler.

Woolridge, J. (1988). Competitive decline and corporate restructuring: Is a myopic stock market to blame? Journal of Applied Corporate Finance, 1(1), 23-36.

Zellweger, T. (2006). Risk, return and value in the family firm. Unpublished dissertation, University of St. Gallen.

Thomas Zellweger is lecturer at the University of St. Gallen in the field of family firm management, and holds the position of co-director of the Center for Family Business at the University of St. Gallen. 